\title{
High Gain Transformer Less Inverter using Buck Boost Converter
}

\author{
Mr. Abhinav V. Deshpande \\ Internal Full Time (IFT) Ph. D. Research Scholar \\ School of Electronics Engineering (SENSE) \\ Vellore Institute of Technology (VIT), Vellore, Tamil Nadu, India-632014 \\ avd.a.deshpande@gmail.com
}

\begin{abstract}
:
In this research paper, a high gain transformer less inverter modeling which is used for the smart grid technology or as the stand alone for home appliances is proposed. The proposed transformer less topology provides a higher voltage gain, low cost, small size and simple control stand alone transformer less inverter for home appliances. The above inverter is modeled by using software which is known as MATLAB/ Simulimk.
\end{abstract}

\section{Keywords:}

High Gain, Single Stage, Switched Inductor Buck Boost Converter

\section{Introduction:}

In order to replace the conservative ways of using the fossil fuel to generate the electricity and replace the gasoline in the automobile industry, using of the renewable energy resources has become increasingly popular. The utilization of the renewable energy resources from a distributed power generation requires the development of an inverter that converts a variable DC output of the renewable energy resources like a photovoltaic and fuel cell into a useful AC. Since the voltage which is produced by the solar cells is not high enough in order to obtain a certain level of the AC voltage through the inverter. There are two main topology groups which are used in the case of a grid connected PV systems, one is by using the DC side a high frequency DC-DC transformer or on the grid side a big bulky AC transformer. Both of these solutions offer the safety and the advantage of galvanic isolation, but the efficiency of the whole system is decreased due to the power losses in these extra components. In case, the transformer is omitted, the efficiency of the whole PV system can be increased with an extra $1 \%-2 \%$. In the transformer less system, a boost mode DC-DC converter is necessary in order to connect in between the solar cells and the inverter. The disadvantage with this two stage system is that they have a relatively lower efficiency, larger size and higher cost. Therefore, the modern day trend is derived towards the single stage grid connected configurations because of their small size, low cost, high efficiency and high reliability. The single stage inverters should do both the functions of boosting the input voltage and converting it into an AC voltage. Therefore, in a single stage grid connected PV systems, the sole power stage must achieve the MPPT, boosting or bucking (if required) and the inversion together. The transformer less inverter in this research paper consists of a switched inductor buck boost converter with a PWM modulation which is followed by a H-Bridge inverter. All the switches of the H-Bridge inverter are switched at $50 \mathrm{~Hz}$ in order to reduce the switching losses and so improving the efficiency of the inverter. The buck boost converter switch is modulated by using a sine wave at a high switching in order to reduce the size of the output filter. The converter operates in the DCM to provide a naturally sinusoidal current with a unity power factor. 


\section{The Proposed Transformer Less Topology:}

In the proposed transformer less inverter buck boost converter used is different than the traditional buck boost converter. The figure shows that the inductor of the traditional buck boost converter is replaced by the switched inductor buck boost converter. By adding the switched inductor, it introduces the advantage of a high voltage gain with it thereby keeping the efficiency almost without change. It consists of a sine modulated buck boost converter which operates in the DCM to provide a unity power factor and to provide a low filter size at the output. The converter switch is the main control switch that can execute the control commands. The H-Bridge inverter switch operates at the $50 \mathrm{~Hz}$ frequency in order to reduce the switching losses and to provide a higher efficiency. It works as a folded cascade unit. During the positive half cycle, the switches SW2 and SW5 are always on and during the negative half cycle, the switches SW3 and SW4 are always on.

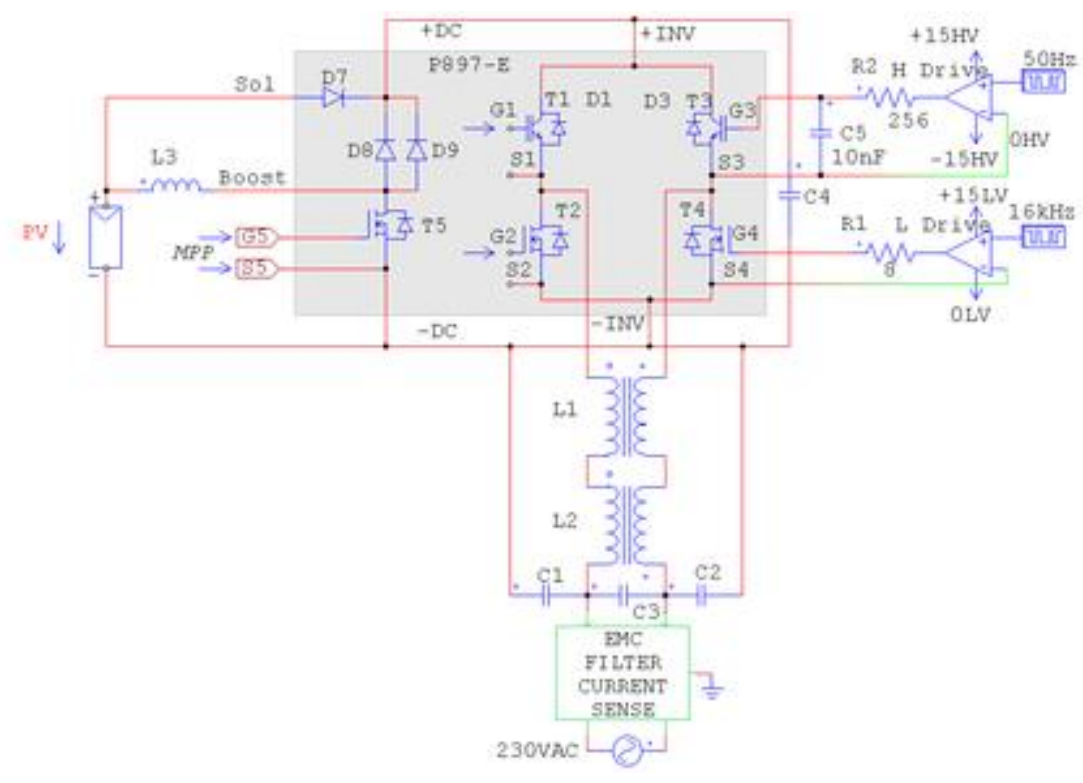

Figure 1 Proposed Transformer less Topology

\section{Operation Mode of Converter:}

\subsection{Mode 1:}

It takes place when SW1 and the diodes D1 and D3 are on. In this case, the steady state equation of the converter is given by the expression which is as follows:

$\mathrm{V}_{\mathrm{L}}=\mathrm{V}_{\mathrm{g}}$

$I_{C}=-v_{0} / R$

\subsection{Mode 2:}

It occurs when the diodes D2 and D4 are on and SW1 is off.

$\mathrm{V}_{\mathrm{L}}=-\mathrm{V}_{0} / 2$

Eqn. (3)

$\mathrm{I}_{\mathrm{c}}=\mathrm{I}_{\mathrm{L}}-\mathrm{V}_{0} / \mathrm{R}$

Eqn. (4)

\subsection{Mode 3:}


It occurs when SW1 and all the other diodes are off. Then, the inductor current becomes zero.

$\mathrm{V}_{\mathrm{L}}=0$

$\mathrm{I}_{\mathrm{c}}=\mathrm{I}_{\mathrm{L}}-\mathrm{v}_{0} / \mathrm{r}$

Figure 2 shows the inductor current and Figure 3 shows the diode D4 current. From the steady state analysis and the balance theory, the average value of the inductor voltage is zero:

$<\mathrm{v}_{\mathrm{L}} \geq 0$

$\left.<\mathrm{i}_{\mathrm{d}}\right\rangle=\mathrm{v}_{0} / \mathrm{R}$

The gain of the converter can be obtained as follows:

$\mathrm{V}_{0} / \mathrm{V}_{\mathrm{g}}=\sqrt{ } 2 * \mathrm{~K}$

where

$\mathrm{K}=\mathrm{D}^{2} * \mathrm{~T}_{\mathrm{S}} * \mathrm{R} / 2 * \mathrm{~L}$

$\mathrm{D}$ is the converter duty cycle, $\mathrm{T}_{\mathrm{S}}$ is the switching period, $\mathrm{L}$ is the converter inductor, and $\mathrm{R}$ is the load resistance. Equation (9) shows that the gain of the converter is higher than the traditional buck boost converter by $\sqrt{2}$. Figure 4 shows a comparison in between the gain of the switched inductor and the traditional buck boost converter. It is clear that the gain of the switched inductor is higher than the traditional buck boost converter, especially for higher duty cycles.



Figure 2 Inductor Current 


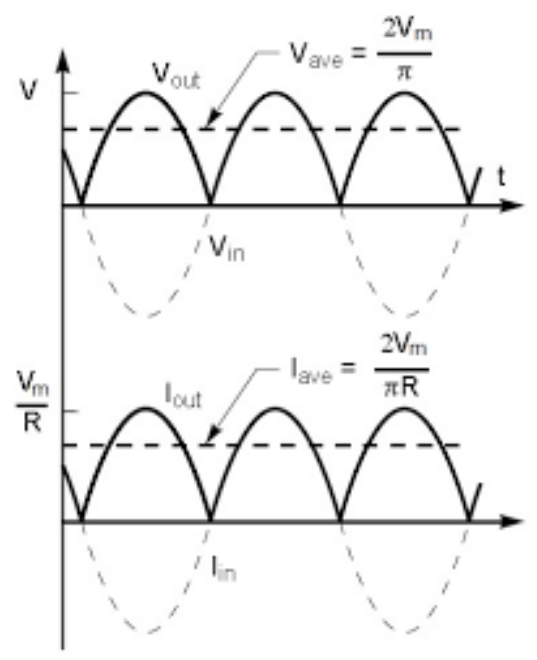

Figure 3 Diode D4 Current

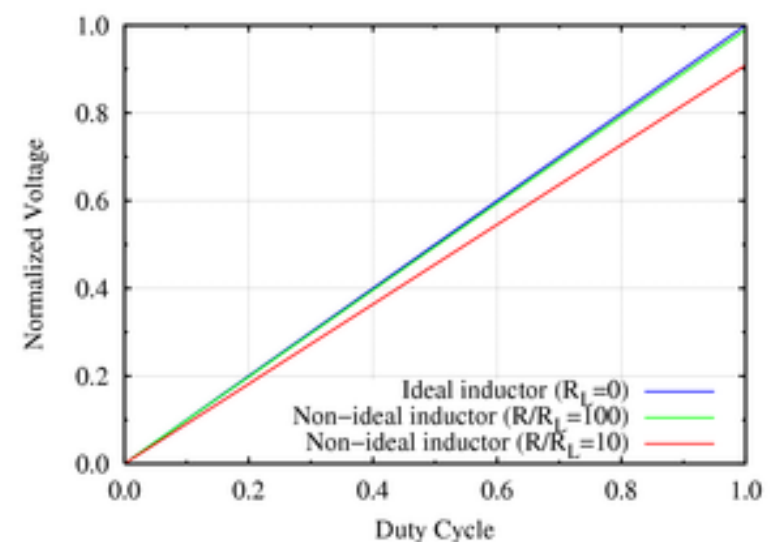

Figure 4 Gain versus Duty Cycle Plot for Buck boost Converter

\section{MATLAB Simulink Diagrams and Results of Inverter:}

The performance of the proposed inverter topology is simulated with the MATLAB/ Simulink software. In the simulation, the supply is the DC source $\mathrm{V}_{\mathrm{dc}}=44$ Volts and the inductance of $\mathrm{L}_{1}=\mathrm{L}_{2}=85 \mu \mathrm{H}$. The inverter is driving a load of $\mathrm{R}=100 \mathrm{ohms}$. The filter capacitor is $1000 \mu \mathrm{F}$. The SPWM method is used to modulate the converter switch. The switching frequency of the converter is $10 \mathrm{KHz}$. 


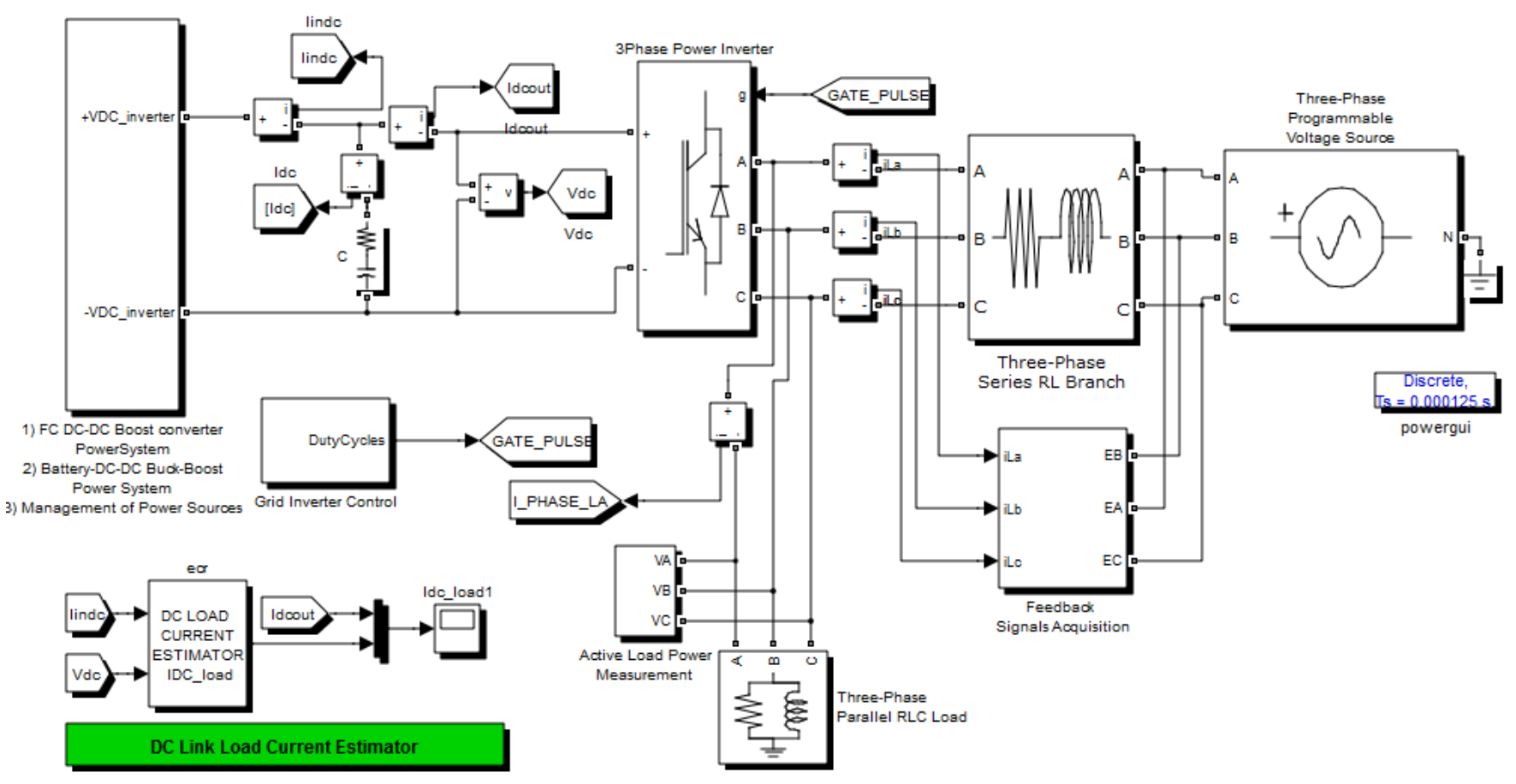

Figure 5 Simulink Diagram of the Proposed Inverter

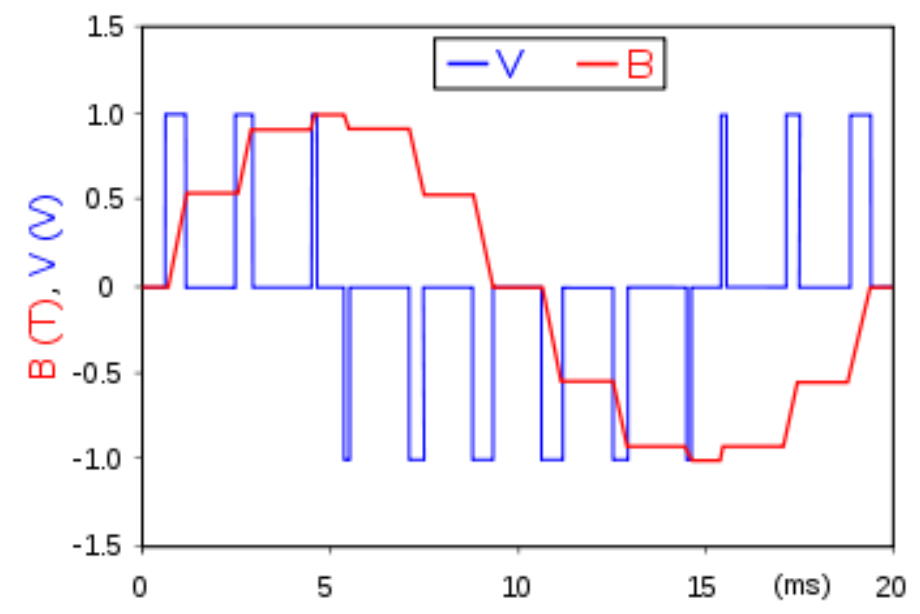

Figure 6 Gate Pulses of SWI 

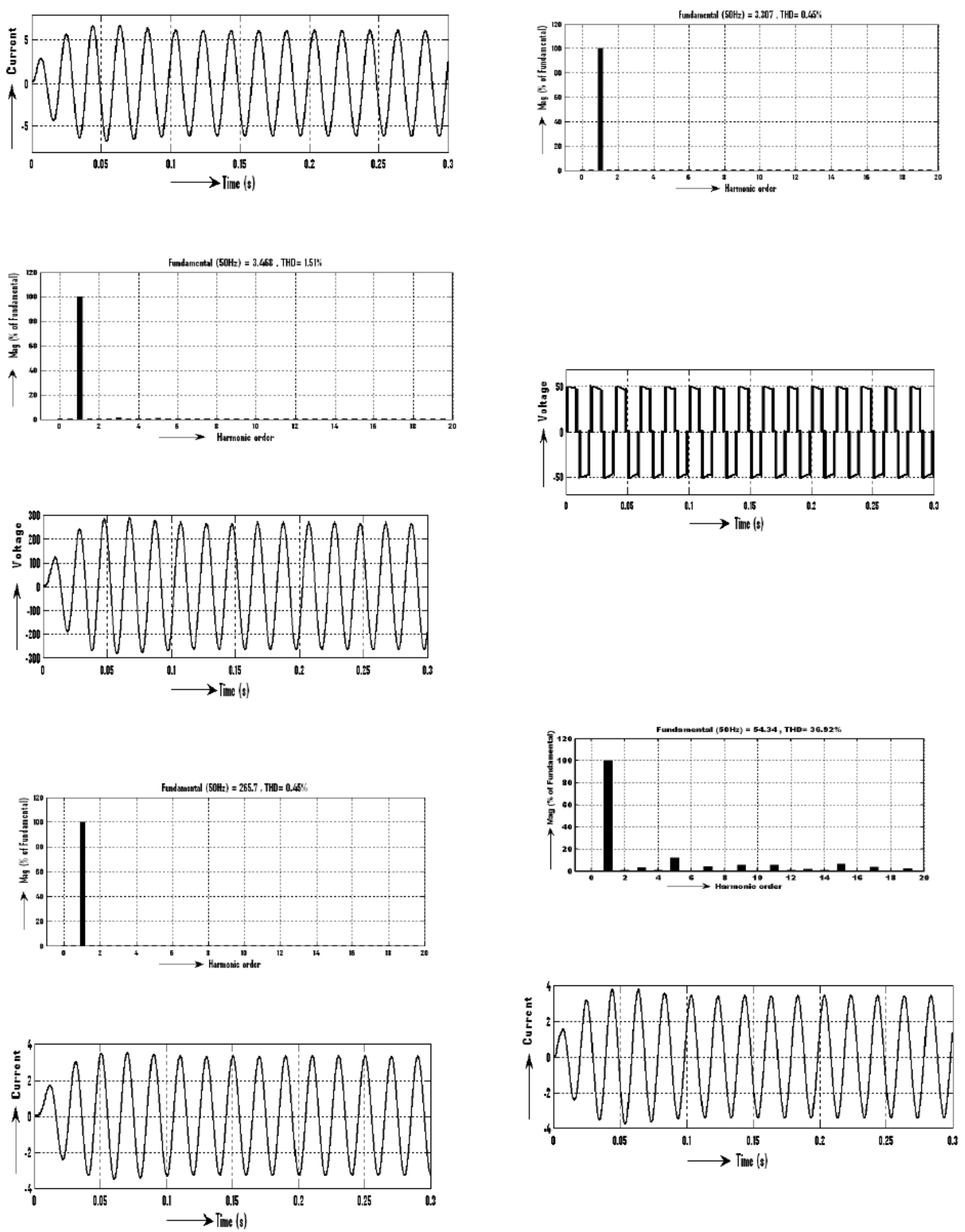

Figure 7 Gate Pulses of SW2SW5 and SW3SW4 

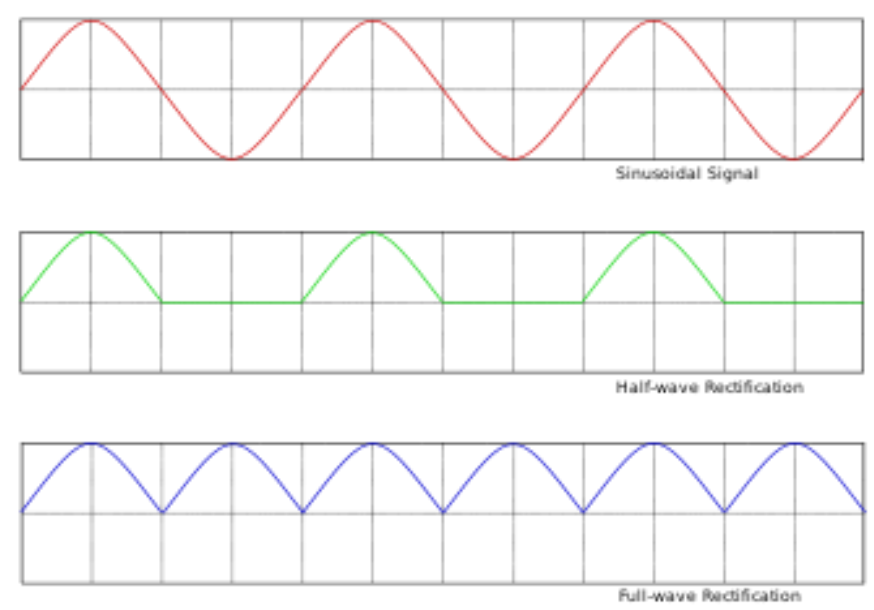

Figure 8 SWI Voltage

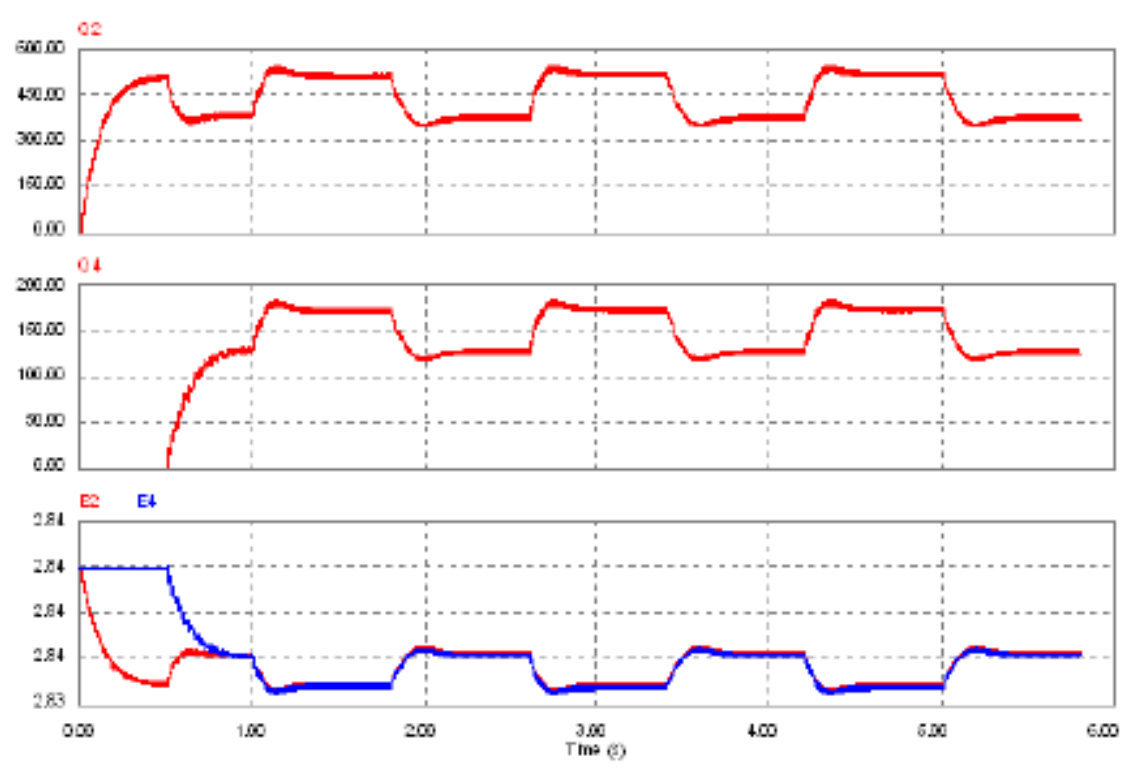

Figure 9 Output Current and Voltage of Inverter 


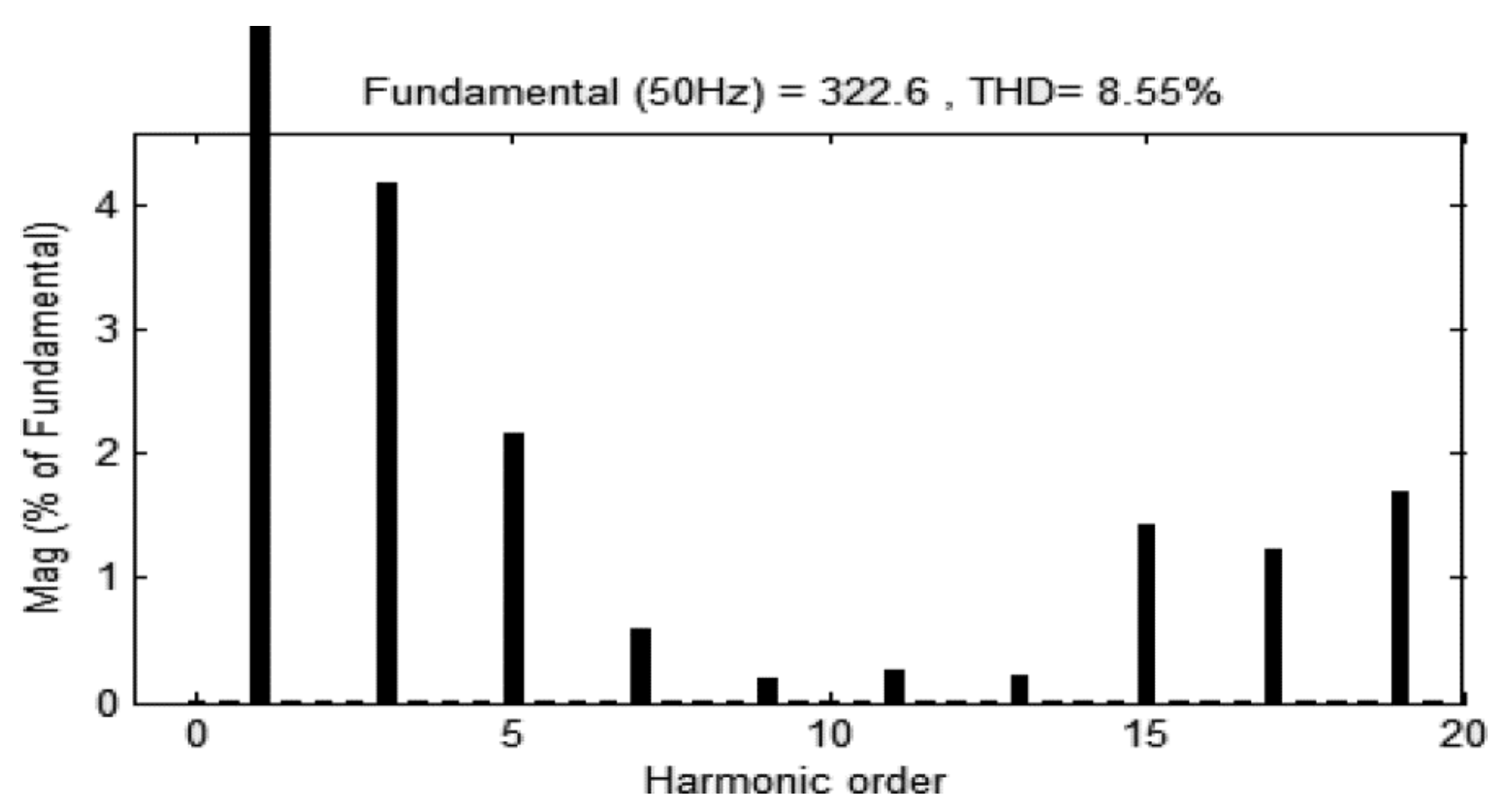

Figure 10 FFT Analysis of Single Phase Single Stage Transformer less Inverter

\section{Conclusion:}

A single phase single stage transformer less inverter proposes a high voltage gain, high efficiency, low switching losses, low cost, small size. The only limitation of the proposed converter is that it operates in the DCM that is the inductor current ripple is higher than the CCM operation that gives a limit to the power rating to be processed, which is the same feature of any DCM operation. However, as the target application is the AC modules where the required power to be processed is in the range of hundred watts. The DCM operation is the suitable choice.

\section{References:}

[1] Omar Abdel-Rahim, IEEE Student Member, Mohamed Orabi, IEEE Senior Member and Mahrous E. Ahmed, IEEE Senior Member, "High Gain Single Stage Inverter for Photovoltaic AC Modules", APEARC, South Valley University, Egypt, IEEE-2011.

[2] B. Axelrod, Y. Berkovich and A. ioinovici, "Switched Capacitor/ Switched Inductor Structures for Getting Transformer less Hybrid DC-DC PWM Converters", IEEE Transactions on Circuits and Systems-I: Regular Papers, Volume 55, No. 2, March 2008.

[3] B. Nagaraju, S. Tarakalyani, A. Srinivasula Reddy, Assistant Professor, Vaagdevi College of Engineering, " Transformer less Inverter for Smart Grid Based on Photovoltaic Systems”, International Journal of Innovative Technology and Creative Engineering (IJITCE), ISSN: 2045-8711, Volume 1,No. 11, November 2011.

[4] R. Lai and K. Ngo, "A PWM Method for Reduction of Switching Loss in a Full-Bridge Inverter", IEEE Transactions on Power Electronics, Volume 10, No. 3, May 1995.

[5] W. N. Mohan, T. Undeland and W. P. Robbins, "Power Electronics: Converters, Applications and Design", New York, Wiley, 2003. 